Пудичева Г.О.

кандидат економічних наук, докторант, Одеський наиіональний економічний університет ORCID: https://orcid.org/0000-0002-9350-3509

\title{
РОЗРОБЛЕННЯ КОНЦЕПТУАЛЬНИХ ЗАСАД ЕНЕРГЕТИЧНОЇ ЛОГІСТИКИ
}

Логістичний підхід в управлінні може застосовуватися в окремих галузях, зокрема в енергетиці, формуючи енергетичну логістику. Автор пропонус визначати ї̈ як науковий напрям та практичну діяльність з управління потоками енергетичних ресурсів, енергетичними потоками та іншими супутніми потоками (включаючи зворотні) від джерела їх утворення до місия кінщевого споживання, яке спрямоване на повне задоволення вимог споживачів та інших зачікавлених сторін за мінімізаиї̈ витрат. У статті визначено мету енергетичної логістики, виходячи з «семи правил логістики», об 'єкт та суб'єкт ї̈ управління. Автором окреслено основні завдання енергетичної логістики на макро- та мікрорівні. Узагальнено приниипи енергетичної логістики, виходячи зі спечифіки використання в енергетичному господарстві. Охарактеризовано концептуальні засади енергетичної логістики.

Ключові слова: енергетична логістика, мета енергетичної логістики, об'єкт енергетичної логістики, приничипи енергетичної логістики, ланиюги поставок в енергетиці, макрологістика, мікрологістика.

Постановка проблеми. Ефективність функціонування економіки значною мірою визначається безпекою, якістю та надійністю енергопостачання, оскільки процеси виробництва, передачі, розподілу та споживання енергії безперервні та нерозривні в часі. Тому для надійного енергозабезпечення доцільно використовувати найбільш дієві підходи до організації та управління енергетичним господарством, серед яких чільне місце має посісти логістика.
Незважаючи на те, що логістика - доволі молода наука, останнім часом з'являється все більше публікацій із питань застосування логістичного підходу в різних галузях народного господарства. Успіх логістики в конкретній галузі залежить від того, як будуть впроваджуватися конкретні логістичні методи, а також як вони будуть налаштовані відповідно до потреб споживачів.

Нині доволі успішно розвиваються такі функціональні області логістики, як логістика постачання, 
виробництва, розподілу, логістика складування, транспортування, запасів. Вони широко застосовуються на практиці сучасними підприємствами, мають розроблене теоретичне підгрунтя та відіграють ключову роль у концепції інтегрованої логістики. Водночас з'являються нові напрями галузевої (предметної) логістики, які мають свої особливості залежно від тієї галузі, в якій формуються, функціонують та розвиваються логістичні системи. До них відносяться такі напрями, як торговельна, промислова, інформаційна, фінансова, банківська, туристична, комерційна логістика, сіті-логістика, «зелена» логістика, логістика обслуговування тощо. Серед них особливе місце повинна зайняти енергетична логістика, оскільки процеси виробництва та споживання енергії супроводжують майже всі господарські процеси сучасних підприємств будь-якої галузі.

Аналіз останніх досліджень і публікацій. Нині є обмежена кількість публікацій із питань енергетичної логістики, ii проблематика залишається недостатньо дослідженою. Серед учених, які займаються питаннями застосування логістичного підходу в енергетичній галузі, слід відзначити І.В. Струтинську, Т.В. Романькову, М.Н. Гриневич, С.В. Смоляго та ін. Управління ланцюгами поставок в енергетиці розглядається в працях А. Халлдорссона, М. Сванберга, Л. Фенга, Л. Мірса, К. Біфорта, Дж. Шульте та ін. Проте досі залишаються несформованими теоретичні та методологічні засади концепції енергетичної логістики та управління ланцюгами поставок в енергетичній сфері.

Мета статті полягає у формуванні теоретичних засад концепції енергетичної логістики, а саме розробленні визначення цього поняття, встановлення мети, об'єкта та суб'єкта логістичного управління в енергетичній сфері, формуванні переліку завдань та принципів.

Виклад основного матеріалу. У сучасній науковій літературі відсутнє загальноприйняте визначення поняття «енергетична логістика». I.В. Струтинська визначає його таким чином: «Енергетична логістика - це наука про оптимізацію енергетичних потоків та управління ними, а також потоками послуг в енергетичній галузі та супутніх інформаційних і фінансових потоків для вирішення поставлених завдань» [1]. На наш погляд, таке визначення фокусує увагу лише на енергетичних потоках, які є за своєю суттю саме потоками послуг, однак не розглядає як об'єкт управління потоки енергетичних ресурсів, що є зазвичай матеріальними потоками.

Т.В. Романькова називає енергетичну логістику концепцією, спрямованою на оптимізацію енергетичних потоків та управління ними [2, с. 34]. Та ж дослідниця, разом із М.Н. Гриневич, наводить таке визначення: «Енергетична логістика - це наука про управління та оптимізацію потоків електроенергії, газу, води, тепла, нафти та ін., що транспортуються нерухомим транспортом (трубопроводами, дротами та ін.), потоків супутніх послуг, а також пов'язаних 3 ними інформаційних та фінансових потоків у відповідних системах електро-, газо-, водо-, тепло-, нафто- та ін. постачання, хімічної промисловості та інших безперервних виробництвах, де використовується велика кількість спільно працюючого обладнання, пов'язаного між собою трубами та/або дротами, для досягнення поставлених перед ними цілей» [3, с. 35]. Однак автори наголошують, що це визначення будується на оптимізації руху енергетичних ресурсів, які переміщуються лише нерухомим транспортом, при цьому не враховується рух енергетичних потоків іншими видами транспорту [3, с. 35]. Вони пропонують розуміти під енергологістикою оперативне управління потоками паливно-енергетичних ресурсів у мікро-, мезо- та макрологістичних системах [4, с. 400]. Крім того, вказані автори визначають логістику як науку та практичний інструментарій, спрямований на забезпечення суб'єктів господарювання паливно-енергетичними ресурсами шляхом управління їх переміщенням з метою задоволення потреб виробництва 3 мінімальними витратами [3, с. 35]. Ми погоджуємося 3 можливістю використання логістичного підходу на різних рівнях енергетичного господарства, що являють собою логістичні системи, однак, на нашу думку, це визначення є доволі дискусійним, оскільки об'єкт управління звужений лише до потоку енергетичних ресурсів, хоча, енергетичне господарство перетворює їх на потоки енергетичних послуг (енергетичні потоки), які мають певні особливості функціонування і також вимагають оптимізації.

Вважаємо, що об'єктом управління в енергетичній логістиці мають бути як потоки енергетичних ресурсів (які також характерні для транспортної логістики, де використовується рухомий транспорт), так і енергетичні потоки. Саме тому можна дати таке авторське визначення енергетичної логістики.

Енергетична логістика - це науковий напрям та практична діяльність з управління потоками енергетичних ресурсів, енергетичними потоками та іншими супутніми потоками (включаючи зворотні) від джерела їх утворення до місия кінцевого споживання, яке спрямоване на повне задоволення вимог споживачів та інших зацікавлених сторін за мінімізації витрат.

Енергетична логістика має забезпечити комплексний підхід у плануванні, організації, контролі та координації логістичних процесів складної системи енергозабезпечення.

Водночас варто вказати на особливості енергетичної логістики, які випливають зі специфіки функціонування енергетичної галузі.

С.В. Смоляго відносить до таких особливостей: безперервний синхронний рух енергетичного потоку в сфері виробництва та розподілу; перетворення матеріального потоку на вході в енергетичний; відокремлену специфічну систему оцінки та управління надійністю; необхідність подолання логістичних бар'єрів, що виникають під час розділення конкурентних та природно-монопольних видів діяльності [5, с. 80].

Н. Григорєва серед особливостей енергетичної галузі називає:

- системність розвитку, пов'язану 3 історичним процесом формування великих систем енергетики за фінансової підтримки держави;

- активність великих систем енергетики, які не тільки виконують функції обслуговуючих галузей, але й значним чином впливають на розвиток і розміщення продуктивних сил;

- пріоритет надійності енергопостачання населення та всієї економіки над економічністю роботи енергетичних компаній, тобто необхідність безперервної та якісної роботи основних елементів системи; 
- високу соціальну та економічну ціну збоїв у функціонуванні енергосистем;

- високу капіталомісткість галузі i, таким чином, необхідність додаткових гарантій, прямої участі держави в проектах залучення фінансових коштів для зниження інвестиційних ризиків галузі;

- необхідність створення та підтримки резервів у виробництві та транспортуванні енергоресурсів;

- здійснення екологічного моніторингу і контролю галузі;

- виключне значення енергопостачальних підприємств у ізольованих та віддалених районах країни [6, с. 38].

Усі ці особливості повинні бути враховані під час здійснення логістичного управління в енергетичній галузі.

Метою енергетичної логістики Т.В. Романькова та М.Н. Гриневич називають розв'язання тактичних та стратегічних завдань комерційної діяльності на основі оптимізації потокових процесів та підвищення ефективності [7, с. 173]. 3 такою думкою важко погодитися, оскільки основною метою логістики взагалі $є$ виконання «семи правил логістики». На наш погляд, мета енергетичної логістики повинна відповідати цим правилам та полягає в забезпеченні відповідного споживача певними енергетичними ресурсами або енергетичними послугами відповідної якості, у відповідній кількості, у правильне місие, у правильний час, з мінімальними витратами. Варто відзначити, що відповідна якість передбачає не лише певні фізико-хімічні властивості потоків енергетичних ресурсів та енергетичних потоків, але й зниження екологічного навантаження під час здійснення процесів їхнього руху.

Об'єктом управління в енергетичній логістиці $\epsilon$ потоки енергетичних ресурсів, енергетичні потоки та інші супутні потоки (включаючи зворотні) в енергетичному господарстві. Суб'єктами управління в енергетичній логістиці є окремі співробітники енергетичного господарства, що виконують логістичні функції, а також структурні одиниці (елементи логістичного ланцюга), що займаються виконанням логістичних завдань.

Енергетичне господарство за своєю суттю є логістичною системою, причому за масштабом сфери діяльності відповідно до рівнів енергетичного господарства також можна виділити мікро-, мезо- та макрологістичні системи. При цьому макрологістична енергетична система охоплює рівень держави, мезологістична енергетична система займає проміжне положення, відповідаючи енергетичному господарству територіального утворення, а мікрологістична енергетична система рівень окремого підприємства. Проте варто звернути увагу на те, що енергетичне господарство підприємства, залежно від того, на якому етапі енергетичного ланцюга працює підприємство, буде мати особливості мікрологістичної системи.

Визначення особливостей функціонування конкретного енергетичного господарства необхідне для того, щоб визначити відповідний інструментарій енергетичної логістики, який допоможе підприємству отримати конкурентні переваги.

Кожен $з$ учасників енергетичного ланцюга постачання, на думку Т.В. Романькової та М.Н. Гриневич, повинен виконувати такі види робіт, як:
1) оцінка потоків енергетичних ресурсів, тобто визначення основних параметрів потоків енергетичних ресурсів, їхніх властивостей з метою вибору технологій зберігання та транспортування;

2) оцінка конфігурації ланцюгів постачань, тобто визначення їх учасників та можливості застосування альтернативних варіантів у разі виникнення непередбачених обставин;

3) оцінка ключових та допоміжних логістичних процесів у ланцюгу постачань, спрямованих на мінімізацію витрат;

4) аналіз взаємодії учасників у ланцюгу постачань при спільному постачанні енергетичних ресурсів та енергії;

5) оцінка внутрішнього середовища учасників ланцюга постачань;

6) аналіз зовнішнього середовища учасників ланцюга постачань;

7) оцінка зовнішнього середовища ланцюга постачань [7, с. 174].

При цьому завдання енергетичної логістики на мікро- та макрорівні будуть відрізнятися (рис. 1).

Методологія енергетичної логістики повинна базуватися на певних принципах. Т.В. Романькова та М.Н. Гриневич називають такі принципи управління потоками, які використовуються в енергетичній логістиці:

- ефективність (постійне зниження показників енергоємності);

- системність (орієнтованість кожного 3 елементів системи на досягнення загальних цілей);

- ієрархічність (організація багаторівневої системи руху потоків в енергетичному господарстві, усунення можливих протиріч та конфліктів у розподілі повноважень між ними);

- функціональність (розподіл функцій між учасниками енергетичного ланцюга, діяльність яких спрямована на ефективне використання ресурсів);

- цілеспрямованість (процеси енергоспоживання повинні відповідати певним цілям);

- науковість (використання прогресивних наукових ідей в управлінні енергетичними процесами);

- гнучкість (можливість швидко пристосовуватися до змін внутрішнього та зовнішнього середовища);

- безперервність (постійне планування, облік та управління) [4, с. 401].

На нашу думку, цей перелік принципів варто розширити відповідно до принципів, які використовуються в загальній теорії логістики.

Варто відзначити, що єдиної думки щодо складу принципів логістики нині немає. Та все ж, проаналізувавши наукову літературу з питань визначення принципів логістики, можна виділити найбільш значущі та дати їм характеристику, виходячи зі специфіки їх використання в енергетичній логістиці (табл. 1).

Розглядаючи принципи логістики, Д. Малінджак визначає логістику як частину кібернетики та виділяє шість ключових критеріїв існування цієї наукової дисципліни: система упередження, системний підхід, принципи та інструменти логістики, об'єкти логістики - потоки та ланцюги, контрольовані змінні та критерії оптимізації [14, с. 48]. Вважаємо, що даний підхід можливо застосувати і для окреслення концептуальних засад енергетичної логістики: 


\begin{tabular}{|c|c|}
\hline \multicolumn{2}{|c|}{ Завдання енергетичної логістики } \\
\hline & $\longrightarrow$ \\
\hline $\begin{array}{c}\text { Мікрорівень } \\
\text { (рівень підприємства) }\end{array}$ & $\begin{array}{c}\text { Макрорівень (рівень енергетичного } \\
\text { ланцюга постачань) }\end{array}$ \\
\hline $\begin{array}{l}\text { планування процесу } \\
\text { енергоспоживання; } \\
\text { організація забезпечення логістичної } \\
\text { системи необхідними ресурсами; } \\
\text { організація своєчасного ремонту } \\
\text { енергетичного устаткування; } \\
\text { вибір джерел енергопостачання } \\
\text { (постачальників енергетичних ресурсів } \\
\text { та/або енергетичних послуг); } \\
\text { встановлення оптимальних режимів } \\
\text { енергозабезпечення споживачів } \\
\text { енергії; } \\
\text { оперативне управління потоками } \\
\text { енергетичних ресурсів, енергетичними } \\
\text { та іншими потоками з урахуванням } \\
\text { витрат; } \\
\text { створення інформаційних систем для } \\
\text { моніторингу, аналізу та контролю } \\
\text { даних про рух потоків енергетичних } \\
\text { ресурсів, енергетичних та ін. потоків; } \\
\text { підвищення енергетичної ефективності } \\
\text { та ін. }\end{array}$ & $\begin{array}{l}\text { вибір схеми розподілу потоків між } \\
\text { організаціями; } \\
\text { проектування та розміщення пунктів } \\
\text { виробництва енергії; } \\
\text { аналіз енергетичного ринку та ринку } \\
\text { енергоресурсів; } \\
\text { визначення потреби в енергетичних } \\
\text { послугах; } \\
\text { моделювання енергетичних потоків } \\
\text { та алгоритмів руху потоків } \\
\text { енергетичних ресурсів та } \\
\text { енергетичних потоків; } \\
\text { регулювання зворотних потоків } \\
\text { енергетичної системи з метою } \\
\text { зниження негативного екологічного } \\
\text { ефекту для навколишнього } \\
\text { середовища; } \\
\text { підвищення доступності та } \\
\text { надійності енергопостачання; } \\
\text { підвищення сталості енергетичних } \\
\text { систем; } \\
\text { розробка енергетичних стратегій } з \\
\text { метою розробки альтернативних } \\
\text { варіантів енергопостачання; } \\
\text { розроблення нових технологій в } \\
\text { сфері енергетики } \\
\text { та ін. }\end{array}$ \\
\hline
\end{tabular}

Рисунок 1 - Завдання енергетичної логістики на мікро- та макрорівні

Джерело: розроблено автором на основі [4, с. 400]

1. Енергетична логістика розглядає об'єкт управління, потоки в енергетичному ланцюгу та мережі як систему. Основним підходом в управлінні є системний підхід.

Енергетичні логістичні системи відповідають загальноприйнятому поняттю «системи», а саме складаються із взаємозалежних системоутворюючих елементів, які мають впорядковані взаємозв'язки та формують певну структуру із заздалегідь визначеними властивостями. Ці системи характеризуються високою узгодженістю для забезпечення управління наскрізними потоками енергетичних ресурсів та енергетичними потоками.

2. Об'єктом управління є потоки енергетичних ресурсів, енергетичні та інші супутні потоки в ланцюгах та мережах, що формуються в енергетичному господарстві.

Потоки в енергетичному господарстві під час свого руху змінюють свої параметри в часі та просторі. Так потоки енергетичних ресурсів (матеріальні потоки) трансформуються в енергетичні потоки (потоки послуг). Усі потоки енергетичного господарства поєднані в ланцюги та мережі, відповідно, від видобутку джерел енергетичних ресурсів через виробництво, передачу, розподіл до споживача. Саме логістичні системи приводять до руху певних елементів пото- ків. При цьому активними елементами є елементи, які продукують рух (в енергетичні логістиці-це машини, енергетичні установки, процеси виробництва, генератори, розподільчі мережі, трубопроводи, лінії електропередачі, трансформатори, передавальні пристрої, люди та ін.), а пасивними елементами потоків - елементи, які рухаються (відновлювальні та невідновлювальні енергетичні ресурси, вторинні енергетичні ресурси, енергія, гроші, інформація та ін.). Інтеграція окремих активних елементів створює рух логістичних потоків.

3. Керованими змінними $є$ час та простір, тому енергетична логістика повинна розглядати управління потоками з точки зору часо-просторової перспективи.

Управляючи логістичними процесами, пов'язаними 3 рухом потоків в енергетичному господарстві, енергетична логістика має справу з такими показниками як, час виробництва, час початку виробничого процесу, використання виробничої потужності, оптимальне сполучення джерел енергії, мінімальні витрати, мінімальний рівень викидів тощо, які можуть бути критеріями оптимізації.

4. Базовим принципом управління $\epsilon$ координація енергетичних процесів у ланцюгу. Цей принцип пов'язаний з наявністю ієрархічних зв'язків в енергетичному логістичному ланцюгу. 


\section{Таблиця 1 - Принципи енергетичної логістики}

\begin{tabular}{|c|c|}
\hline Назва принципу & Специфіка використання принципу в енергетичній логістиці \\
\hline Системність & $\begin{array}{l}\text { Розгляд основних та супутніх потоків всередині енергетичного господарства як системи. Розгляд } \\
\text { діяльності енергетичного господарства як логістичного процесу. }\end{array}$ \\
\hline Науковість & $\begin{array}{l}\text { Застосування економіко-математичних методів і моделей на всіх стадіях управління потоками в } \\
\text { енергетичному господарстві. Орієнтація на досягнення науково-технічного прогресу. }\end{array}$ \\
\hline Комплексність & $\begin{array}{l}\text { Формування розвинутої інфраструктури для здійснення руху потоків в енергетичному } \\
\text { господарстві, співпраця та координація дій учасників енергетичного ланцюга, }\end{array}$ \\
\hline Надійність & $\begin{array}{l}\text { Виявлення та усунення перешкод руху основних та супутніх потоків енергетичного } \\
\text { господарства; попередження збоїв. }\end{array}$ \\
\hline $\begin{array}{l}\text { Соціальна та економічна } \\
\text { доцільність, ефективність }\end{array}$ & $\begin{array}{l}\text { Учасники енергетичного ланцюга повинні задовольняти вимоги кінцевих споживачів з } \\
\text { мінімальними витратами, уникаючи вчинення шкоди суспільству та навколишньому середовищу. }\end{array}$ \\
\hline Ініціативність & $\begin{array}{l}\text { Можливість самостійного здійснення взаємовідносин з попереднім та наступним учасником } \\
\text { енергетичного ланцюга. }\end{array}$ \\
\hline $\begin{array}{l}\text { Адаптивність } \\
\text { (гнучкість, варіантність) }\end{array}$ & $\begin{array}{l}\text { Можливість учасників руху потоків в енергетичному господарстві швидко реагувати на зміни } \\
\text { зовнішнього середовища. }\end{array}$ \\
\hline Конкретність & Чітке визначення мети та результатів, які планується досягти в енергетичному господарстві. \\
\hline Конструктивність & Розробка чіткої схеми руху потоків в енергетичному господарстві та оперативне управління в її рамках. \\
\hline Інтегративність & $\begin{array}{l}\text { Tериторіальна, технологічна, економічна єдність учасників енергетичного господарства повинна } \\
\text { бути доповненою інформаційною та структурною єдністю. } \\
\end{array}$ \\
\hline Превентивність & $\begin{array}{l}\text { Попередження виникнення негативних станів та явищ в процесі здійснення роботи } \\
\text { енергетичного господарства. }\end{array}$ \\
\hline Глобальної оптимізації & $\begin{array}{l}\text { Узгодження приватних цілей функціонування елементів системи енергетичного господарства } \\
\text { підприємств для досягнення глобального оптимуму. }\end{array}$ \\
\hline Комп’ютеризації & $\begin{array}{l}\text { Максимальна автоматизація логістичних функцій та процесів в енергетичному господарстві, } \\
\text { що дає можливості для моніторингу, аналізу та розробки необхідних заходів з підвищення } \\
\text { ефективності енергетичного ланцюга. }\end{array}$ \\
\hline Тотальних витрат & $\begin{array}{l}\text { Мінімізація усіх витрат на шляху руху енергії від джерел енергетичних ресурсів до кінцевого } \\
\text { споживача. Точне вимірювання всіх логістичних витрат. }\end{array}$ \\
\hline $\begin{array}{l}\text { Використання теорії } \\
\text { компромісів }\end{array}$ & $\begin{array}{l}\text { Гармонізація економічних інтересів усіх учасників енергетичного ланцюга. Зниження прибутку } \\
\text { (підвищення витрат) в одному з елементів можливе лише за умови збільшення прибутку } \\
\text { (зниження витрат) усієї системи в цілому. }\end{array}$ \\
\hline
\end{tabular}

Джерело: розроблено автором на основі [8, с. 51-54; 9, с. 263-264; 10, с. 24-26;11, c. 118-119; 12; 13, с. 49; 74]

Координація сприяє виконанню не лише цілей окремих підприємств в енергетичному ланцюгу (мікрорівень), але й системи цілей енергетичного ланцюга загалом (макрорівень). Критеріями здійснення успішної координації $є$ мінімізація грошових витрат, мінімізація втрат енергії, мінімізація задіяних ресурсів в енергетичному господарстві, зниження екологічного навантаження, розширення доступу до енергетичних послуг.

5. Базовим принципом управління в енергетичному ланцюзі є принцип упередження, який використовує методи планування.

Потоки в енергетичному господарстві є за своєю природою динамічними об'єктами, що змінюють свій стан в просторі та часі. Однак, енергетична галузь за своєю природою $є$ доволі інертною. Саме тому, енергетична логістика повинна грунтуватися на розробці планів та програм з виробництва, постачання, споживання енергії тощо, а також коректуватися в оперативному управлінні відповідно до принципу зворотного зв'язку.

6. Головною метою енергетичної логістичної системи $\epsilon$ загальна оптимізація ланцюгів та мереж, яка дуже часто є багатокритеріальною.

Загальна оптимізація в енергетичній логістиці передбачає, що глобальний критерій для оптимізації всього енергетичного ланцюга поєднує локальні критерії кожного елемента цього ланцюга. Таким глобальним критерієм може бути мінімізація витрат, максимізація прибутку, в той час як критеріями оптимізації окремих ланок енергетичного ланцюга можуть бути максимізація коефіцієнту корисної дії енергетичної установки, мінімізація часу доставки енергетичних ресурсів, мінімізація втрат тощо. Саме тому в енергетичній логістиці повинні використовуватися методи багатокритеріальної оптимізації.

Основними методами для досягнення загальної мети в енергетичній логістиці повинні стати: методи економіко-математичного моделювання, евристичні методи аналізу, багатокритеріальна оптимізація, методи системного аналізу, прогнозування та ін.

Висновки. Таким чином, енергетична логістика спрямована на забезпечення споживачів певними енергетичними ресурсами або енергетичними послугами відповідної якості, у відповідній кількості, у правильне місце, у правильний час, з мінімальними витратами. Вважаємо, що використання основних засад енергетичної логістики дасть змогу не тільки підвищити економічну ефективність діяльності підприємств у сфері виробництва, передачі, розподілу та споживання енергії, але й покращити таку діяльність у соціальному та екологічному аспектах, тобто підтримати певний рівень сталості енергетичного господарства.

Для вітчизняної економіки підвищення енергетичної ефективності підприємств має стати одним із пріоритетних напрямів розвитку, причому це стосується суб'єктів господарювання на кожному етапі енергетичного ланцюга. 


\section{Список використаних джерел:}

1. Струтинская И.В. Энергетическая логистика - путь к эффективному управлению единственной энергосистемой стран CHГ. URL: http://www.rusnauka.com/22 PNR_2013/Economics/11_142892.doc.htm (дата звернення: 17.07.2020).

2. Романькова Т.В. Энергетическая логистика: эволюция и развитие. Russian Economic Bulletin. 2019. Том 2, № 2. С. 32-39.

3. Гриневич М.Н., Романькова Т.В. Энергетическая логистика: понятие и функциональный контур. Управление в couиальных и экономических системах : м-лы XXVII международной научно-практической конференции, г. Минск, 17 мая 2018 г. / редкол.: Н.В. Суша (предс.) и др.; Минский инновационный ун-т. Минск : Минский инновационный университет, 2018. URL: http://elibrary.miu.by/conferences!/item.uses/issue.xxvii/article.15.html (дата звернення: 17.07.2020).

4. Романькова Т.В., Гриневич М.Н. Энергологистика - наука и практика управления энергоресурсами на промышленных предприятиях. Материаль, оборудование и ресурсосберегающие технологии : материалы международной научно-технической конференции, Могилев, 24-25 апреля 2014 г. / ред.: И. С. Сазонов [и др.]. Могилев : Белорусско-Российский университет, 2014. C. $400-401$.

5. Смоляго С.В. Специфика логистических систем предприятий энергетики. Опыт и проблемы реформирования системы менеджмента на современном предприятии: тактика и стратегия : сборник статей XVII Международной научно-практической конференции, февраль, 2017. Пенза, 2017. С. 77-81.

6. Григорьева Н. Особенности потоковых процессов в энергетической логистике. РИСК: Ресурсы, Информация, Снабжение, Конкуренщия. 2012. № 4. С. 38-40.

7. Романькова Т.В., Гриневич М.Н. Энергологистика: необходимость и перспективы применения в промышленности Республики Беларусь. Проблемы и вызовы экономики региона в условиях глобализащии : IV Национальная научно-практическая конференция, 19 декабря 2018 г., Комрат / под общ. ред.: Тодорич Л. П. ; редкол.: Дмитрий Пармакли [и др.]. Комрат: US Comrat, 2018 (Tipogr. "Centrografic"). Т. 2: Управление финансами на национальном и региональном уровне. Актуальные проблемы развития маркетинга и туризма. Актуальные проблемы и перспективы развития бухгалтерского учета. С. $173-176$.

8. Гаджинский А.М. Логистика : Учебник. 15-е изд., перераб. и доп. Москва : Издательско-торговая корпорация «Дашков и К», 2007. 472 c.

9. Іванова М.І. Принципи як основа наукової методології управління логістикою. Бізнес-інформ. 2015. № 11. С. $261-266$.

10. Хромов О.П. Логістика : Навчальний посібник. Харків : БУРУН КНИГА, 2012. 224 с.

11. Паламарчук И.Н., Сторожилова У.Л. Применение принципов логистики в управлении компанией. Бізнес Інформ. 2011. № 1. C. 117-119.

12. Скоробогатова Т.Н. Традиционная и сервисная логистика: разграничение и взаимопроникновение. Фундаментальные исследования. 2014. № 11, ч. 2. С. 393-398.

13. Дудар Т.Г., Волошин Р.В. Основи логістики : навч. посіб. Київ : Центр учбової літератури, 2012. 176 с.

14. Malindžák D. The Basic Principle of Logistic Theory. Applied Mechanics and Materials. 2015. Vol. 708. Pp. 47-52.

\section{References:}

1. Strutinskaya I.V. (2013). Energeticheskaya logistika - put' k effektivnomu upravleniyu yedinstvennoy energosistemoy stran SNG [Energy logistics - way towards the efficient management of unite energy system of CIS countries]. Available at: http://www.rusnauka.com/22 PNR 2013/Economics/11 142892.doc.htm (accessed 17.07.2020).

2. Roman'kova T.V. (2019). Energeticheskaya logistika: evolyutsiya i razvitiye [Energy logistics: evolution and development]. Russian Economic Bulletin, vol. 2, no. 2, pp. 32-39.

3. Grinevich M.N., Roman'kova T.V. (2018). Energeticheskaya logistika: ponyatiye i funktsional'nyy kontur [Energy logistics: concept and functional contour]. Proceeding of Management in social and economic systems (Belarus, Minsk, May 17, 2018) (eds. N.V. Susha et al.). Minsk: Minsk Innovation University. Available at: http://elibrary.miu.by/conferences!/item.uses/issue.xxvii/ article.15.html (accessed 17.07.2020).

4. Grinevich M.N., Roman'kova T.V. (2014). Energologistika - nauka i praktika upravleniya energoresursami na promyshlennykh predpriyatiyakh [Energy logistics - science and practice of energy resource management at industrial enterprise]. Proceeding of the Materials, equipment and resource saving technologies (Belarus, Mogilev, April 24-25, 2014) (eds. I.S. Sazonov et al.). Mogilev: Pelarus-Russian University, pp. 400-401.

5. Smolyago S.V. (2017). Spetsifika logisticheskikh sistem predpriyatiy energetiki [Specifics of logistics systems of energy enterprises] Proceedings of the Experience and problems of reforming of management system at modern enterprise: tactics and strategy (Russian Federation, Penza, February 2017). Penza, pp. 77-81.

6. Grigor'yeva N. (2012). Osobennosti potokovykh protsessov v energeticheskoy logistike [Features of flow processes in energy logistics]. RISK: Resursy, Informatsiya, Snabzheniye, Konkurentsiya [RISK: Resources, Information, Supply, Competitiveness], no. 4, pp. 38-40.

7. Roman'kova T.V., Grinevich M.N. (2018). Energologistika: neobkhodimost' i perspektivy primeneniya v promyshlennosti Respubliki Belarus' [Energy logistics: necessity and perspectives of application in industial sector of Belarus Republic] Procceding of the Problems and challeneges of region economics in terms of globalization (Moldova, Komrat, December 19, 2018) (eds. Todorich L.P.; Dmitriy Parmakli et al.). Komrat: US Comrat (Tipogr. "Centrografic"), vol. 2, pp. 173-176.

8. Gadzhinskiy A.M. (2007). Logistika [Logistics]. Moscow: «Dashkov i K». (in Russian)

9. Ivanova M.I. (2015). Pryntsypy yak osnova naukovoi metodolohii upravlinnia lohistykoiu [Principles as a basis of scientific methodology of logistics management]. Business Inform, no. 11, pp. 261-266.

10. Khromov O.P. (2012). Lohistyka [Logistics]. Kharkiv: BURUN KNYHA. (in Ukrainian)

11. Palamarchuk I.N., Storozhilova U.L. (2011). Primeneniye printsipov logistiki v upravlenii kompaniyey [Application of logistics principles in company management]. Biznes Inform [Business Inform], no. 1, pp. 117-119.

12. Skorobogatova T.N. (2014). Traditsionnaya i servisnaya logistika: razgranicheniye i vzaimoproniknoveniye [Traditional and service logistics: delimitation and interpenetration]. Fundamental'nyye issledovaniya [Fundamental research], no. 11, vol. 2, pp. 393-398.

13. Dudar T.H., Voloshyn R.V. (2012). Osnovy lohistyky [Basics of logistics]. Kyiv: Tsentr uchbovoi literatury. (in Ukrainian)

14. Malindžák D. (2015). The Basic Principle of Logistic Theory. Applied Mechanics and Materials, vol. 708, pp. 47-52. 
Pudycheva Halyna

Odesa National Economic University

\section{DEVELOPMENT OF CONCEPTUAL BASIS OF ENERGY LOGISTICS}

Reliable energy supply requires the use of the most effective approaches to the organization and management in energy sector, among which the leading place should be occupied by logistics. The logistics approach in management can be applied in different economic sectors, in particular, in energy sector, forming the new branch of logistics, energy logistics. The purpose of this article is to form the theoretical basis of energy logistics concept, namely, to develop a definition of this concept, to establish the purpose, object and subject of logistics management in the energy sector, to form a list of tasks and principles. To achieve this purpose the author applies the following methods: systematization, generalization, scientific abstraction, analysis and synthesis, dialectical method. The author proposes to define energy logistics as a scientific direction and practical activities for the management of flows of energy resources, energy flows and other related flows (including reverse) from the source to the place of final consumption, which aims to meet the needs of consumers and other stakeholders while minimizing costs. The article defines the purpose of energy logistics, based on the "seven rules of logistics", namely, providing the relevant consumer with certain energy resources or energy services of right quality, in the right quantity, in the right place, at the right time, with minimal costs. The object and subject of energy logistics are also defined in the article. The author outlines the main tasks of energy logistics at the macro and micro levels. The principles of energy logistics are generalized, based on the specifics of use in the energy sector. The conceptual principles of energy logistics are described. In order to achieve the goal of energy logistics the following methods should be used: economic and mathematical modeling, heuristic methods of analysis, multicriteria optimization, methods of systems analysis, forecasting, etc. The implementation of energy logistics concept in the energy management will increase the economic efficiency of enterprises, as well as improve social and environmental efficiency, and will lead to the achievement of energy sector sustainability.

Key words: energy logistics, goal of energy logistics, object of energy logistics, principles of energy logistics, energy supply chain, macrologistics, micrologistics.

JEL classification: Q40, M11, O13, O20. 